\title{
Preference for flavoured foods by lambs conditioned with intraruminal administration of nitrogen
}

\author{
BY JUAN J. VILLALBA AND FREDERICK D. PROVENZA \\ Department of Rangeland Resources, Utah State University, Logan, Utah 84322-5230, USA
}

(Received 2 December 1996 - Revised 19 March 1997 - Accepted 17 April 1997)

\begin{abstract}
We suggested that food preference depends on the interplay between flavour and post-ingestive effects, and we predicted that protein-restricted lambs would acquire preferences for foods paired with supplemental sources of $N$, including urea (Expts 1 and 2), casein (Expt 3), and gluten (Expt 4). In each experiment, twenty lambs, in two groups of ten, were conditioned as follows: on oddnumbered days, lambs in group 1 received wheat straw (Expts 1, 3, and 4) or ground barley (Expt 2) flavoured with a distinctive flavour, and lambs in group 2 received the same food but with a different flavour. On even-numbered days, flavours were switched and lambs received capsules containing different amounts of urea (ranging from 0.12 to $0.92 \mathrm{~g} \mathrm{~N} / \mathrm{d}$ ), casein (ranging from 0.23 to $0.69 \mathrm{~g} \mathrm{~N} / \mathrm{d}$ ), or gluten (ranging from 0.23 to $0.69 \mathrm{~g} \mathrm{~N} / \mathrm{d}$ ). After conditioning periods of $8 \mathrm{~d}$, lambs were given a two-choice test to determine preference for flavours paired with $\mathbf{N}$. In Expts 1 and 2, lambs preferred the flavours conditioned with urea at lower doses $(0.12 \mathrm{~g} \mathrm{~N} / \mathrm{d}$ in Expt $1,0.23$ and $0.46 \mathrm{~g} \mathrm{~N} / \mathrm{d}$ in Expt 2), but they avoided the flavour associated with urea at the highest dose (0.23 $\mathrm{g} \mathrm{N} / \mathrm{d}$ in Expt 1 and $0.92 \mathrm{~g} \mathrm{~N} / \mathrm{d}$ in Expt 2). In Expts 3 and 4, lambs avoided the flavours associated with the lowest doses of casein or gluten $(0.23 \mathrm{~g} \mathrm{~N} / \mathrm{d})$, but they preferred the flavours paired with casein or gluten at higher doses $(0.46$ and $0.69 \mathrm{~g} \mathrm{~N} / \mathrm{d})$. After conditioning, $\mathrm{N}$ administrations were suspended and lambs in Expts 3 and 4 were offered a choice of the two flavours at weekly intervals for 2 weeks (extinction); preferences persisted during extinction. Collectively, these results suggest that the postingestive effects of $\mathrm{N}$ in different forms and concentrations influenced the development of food preferences by lambs.
\end{abstract}

Food preferences: Flavour: Urea: Casein: Gluten: Lambs

The food preferences of ruminants appear to be controlled by dietary cues (i.e. the flavour of a food) associatively conditioned by the post-ingestive actions of the food (Provenza, 1995a). Lambs prefer the flavours of foods that contribute to their energy needs (Burritt \& Provenza, 1992; Ralphs et al. 1995; Villalaba \& Provenza, 1996, 1997).

Besides energy, the $\mathrm{N}$ content of foods could also be instrumental in the development of preference. Non-ruminant animals choose qualities and quantities of protein in accordance with their physiological needs (Gibson \& Booth, 1986; Baker et al. 1987; Booth, 1991). Rats acquire aversions to amino acid (AA)-deficient diets, and can learn to select a solution containing the one AA that rectifies the dietary-induced imbalance (Gietzen et al. 1986; Gietzen, 1993).

Ruminants are usually perceived to be less constrained that non-ruminants with regard to the quality and quantity of protein they must ingest. This is because their primary source of protein (i.e. microbial protein) is synthesized in the rumen, where $\mathrm{N}$ is continually recycled for re-utilization (Owens, 1988). Nevertheless, when rumen protein synthesis is limited or when protein requirements are high, certain microbial AA may fall below 
optimal levels for animal production (Storm \& Ørskov, 1984; Merchen \& Titgemeyer, 1992), which might lead to the development of food aversions (Egan \& Rogers, 1978; Provenza, 1996).

Our objective was to test the hypothesis that post-ingestive effects of $\mathrm{N}$ modify the food preferences of lambs. To test this hypothesis we ascertained if lambs formed preferences for foods (wheat straw in Expts 1, 3 and 4; ground barley in Expt 2) consumed before the intraruminal administration of $\mathrm{N}$ in three different forms: urea (non-protein- $\mathrm{N}$; Expts 1 and 2), casein (ruminally-degradable protein; Expt 3), and gluten meal (escape protein (low rumen degradability); Expt 4).

\section{MATERIALS AND METHODS}

We conducted four experiments at the Green Canyon Ecology Center, located at Utah State University in Logan, Utah. All animals (Finn-Polypay-Suffolk crossbred lambs of both sexes) were individually penned and had free access to salt blocks and fresh water.

\section{Expt 1. Urea and straw}

In this experiment, we determined whether lambs preferred flavoured straw that was paired with a non-protein- $\mathrm{N}$ source (urea) that is rapidly degraded to $\mathrm{NH}_{3}$ in the rumen.

Throughout the experiment, and on a daily basis, lambs were given flavoured wheat straw at 08.00 hours and at 12.00 hours refusals were collected and weighed. Lambs were then given a basal ration ( $760 \mathrm{~g} / \mathrm{d}$ during the familiarization period; $750 \mathrm{~g} / \mathrm{d}$ during conditioning) of lucerne (Medicago sativa) pellets and barley $(55: 45, \mathrm{w} / \mathrm{w})$.

Familiarization period. Twenty lambs, aged $3-4$ months $(15 \mathrm{~kg}$ body weight $(\mathrm{BW}))$, were randomly divided into two groups. On even-numbered days, one group was offered oregano (Origanum vulgare)-flavoured wheat straw (10-20 mm particle size; group 1) and the second group was offered onion (Allium cepa)-flavoured wheat straw (group 2). Flavours (Pacific Foods, Washington, USA) were mixed with straw at a concentration of $10 \mathrm{~g} / \mathrm{kg}$. On odd-numbered days, flavours were switched so that lambs in group 1 received onion-flavoured straw and lambs in group 2 received oregano-flavoured straw. Familiarization with flavoured straw lasted $8 \mathrm{~d}$.

Initial flavour preference. After the familiarization period, lambs received oreganoand onion-flavoured straw simultaneously for $20 \mathrm{~min}$, and intake of each flavoured food was measured. Each lamb's preference (i.e. before any treatment) for each flavour was determined. Lambs were then sorted in decreasing order by initial preference for one flavour (e.g. onion) and pairs of lambs were randomly assigned to two groups (groups 1 and 2). Thus, differences between groups due to initial flavour preferences were balanced since lambs that preferred onion (or oregano) were evenly divided between groups.

Conditioning. Exposure to flavoured wheat straw for groups 1 and 2 followed the procedures described previously: during even-numbered days, group 1 received oreganoflavoured straw and group 2 received onion-flavoured straw. Immediately after lambs began to eat the straw, gelatin capsules containing urea (providing $0.23 \mathrm{~g} \mathrm{~N} / \mathrm{d}$ ) were administered with a balling gun (treatment 1). On odd-numbered days, flavours were switched and immediately after lambs consumed the straw, we introduced a balling gun into each lamb's throat for a few seconds (treatment 2). The basal ration $(750 \mathrm{~g} / \mathrm{d}$ ) of lucerne pellets and barley plus straw and urea $(0.23 \mathrm{~g} \mathrm{~N} / \mathrm{d})$ provided about $80 \%$ of the crude protein $(\mathrm{N} \times 6.25)$ requirements of the lambs (National Research Council, 1985). Each conditioning period lasted $8 \mathrm{~d}$, and there were three conditioning periods. 
During period 1 , when lambs received urea providing $0.23 \mathrm{~g} \mathrm{~N} / \mathrm{d}$ on even days, lambs developed a strong aversion to the flavours paired with urea. To determine whether the aversion could be reversed, we conducted two new conditioning periods (periods 2 and 3 ) in which the amount of urea was reduced to supply $0.12 \mathrm{~g} \mathrm{~N} / \mathrm{d}$. To control for the possible carry-over effects of learned flavour aversions acquired during period 1 , all animals were sorted again in decreasing order by initial preference for one flavour (e.g. onion) and randomly re-assigned to two new groups (groups 1 and 2). This re-assignment was performed only after period 1 of Expt 1 . For the rest of the experiments, lambs did not acquire strong aversions that could have altered the development of future preferences due to carry-over effects.

The amount of straw offered on even-numbered days was equal to a lamb's intake of straw the previous day, which controlled for exposure to the flavoured straw. When averaged across the three conditioning periods lambs consumed 44 (SEM 2.26) $\mathrm{g} / \mathrm{d}$ when flavoured straw was not paired with urea and 47 (SEM 2.52) g/d when flavoured straw was paired with urea.

Preference tests. After each $8 \mathrm{~d}$ conditioning period and at 08.00 hours, preference tests were performed to determine whether lambs preferred flavours paired with $\mathrm{N}$. During each test lambs received oregano- and onion-flavoured straw simultaneously for $20 \mathrm{~min}$, and intake of each flavoured food was measured. Preference tests were conducted on two consecutive days. No $\mathbf{N}$ was supplied during preference tests.

Preference in the present study refers to the amount of test food with a particular flavour ingested relative to the amount of test food consumed containing the alternative flavour. A preference occurred when the quantity consumed of one flavour was higher than the quantity consumed of the alternative flavour.

Our objective was to determine whether intake of a flavoured food previously paired with $\mathrm{N}$ changed in relation to the same food (containing a different flavour) not paired with $\mathrm{N}$. We did not know the concentrations of $\mathrm{N}$ required to modify preference. Thus, for all our experiments the level of $\mathrm{N}$ administered varied (and was confounded) with period of conditioning. In addition, the amount of exposure (i.e. familiarity) to the test foods increased as the number of days of conditioning increased. Nevertheless, familiarity with the test foods (and flavours) was equal for all animals in every period. Thus, during preference tests the difference between consumption of flavoured foods paired or not with $\mathrm{N}$ reflected the effects of $\mathrm{N}$ conditioning (i.e. intake of flavours not paired with $\mathrm{N}$ controlled for exposure effects). Thus, even if familiarity enhanced intake of all flavoured foods, a relative increment in intake of flavoured foods paired with $\mathrm{N}$ indicated the development of a preference as a result of $\mathrm{N}$ conditioning.

\section{Expt 2. Urea and barley}

Wheat straw, the source of carbohydrate in Expt 1, is not rapidly fermentable and it is fermented more slowly than urea, which may result in the suboptimal use of N (Matras et al. 1991; Sinclair et al. 1993), especially at higher doses of urea. In Expt 2, we determined whether changing the source of carbohydrate affected the development of food preferences.

A new group of twenty lambs, aged 3-4 months (18 kg BW), was subjected to the same familiarization and conditioning procedures as those used in Expt 1 . The test food was ground barley $(360 \mathrm{~g} / \mathrm{d})$, and it contained the same flavours as those used in Expt 1; urea was the $N$ source. The basal diet consisted of lucerne pellets $(450 \mathrm{~g} / \mathrm{d})$. Flavoured barley was offered at 08.00 hours every day and lucerne pellets were fed at 12.00 hours. 
The barley plus lucerne pellets and urea $(0.23 \mathrm{~g} \mathrm{~N} / \mathrm{d})$ provided about $80 \%$ of the crude protein requirements of the lambs (National Research Council, 1985).

We conducted five $8 \mathrm{~d}$ periods of conditioning. On odd-numbered days, lambs received urea that represented $0.23($ period 1$), 0.35($ period 2$), 0.46($ period 3$), 0.69($ period 4), and 0.92 (period 5) g N/d. Preference tests were conducted at the end of each conditioning period as described previously.

\section{Expt 3. Casein and straw}

The objective of this experiment was to determine whether a protein that is rapidly degraded to $\mathrm{NH}_{3}$ in the rumen (casein) conditioned preferences for flavoured wheat straw in lambs.

Every day at 08.00 hours lambs were given flavoured straw and the lucerne pelletbarley $(55: 45$, w/w) diet $(860 \mathrm{~g} / \mathrm{d})$ at 12.00 hours. The basal diet, straw and casein $(0.23 \mathrm{~g} \mathrm{~N} / \mathrm{d})$ provided about $80 \%$ of the crude protein requirements of the lambs (National Research Council, 1985).

Lambs from Expt 1 (21 kg BW) were used in Expt 3, but maple and anise (Agrimerica Inc., Northbrook, IL, USA) were used as flavours. All procedures of familiarization and conditioning were as outlined for Expt 1. Lambs were subjected to three $8 \mathrm{~d}$ conditioning periods in which they received capsules containing casein to supply 0.23 (period 1), 0.46 (period 2), and 0.69 (period 3) g N/d on even days. Preference tests were conducted at the end of each conditioning period, as described previously. On average, lambs consumed 88 (SEM 1.77) $\mathrm{g} / \mathrm{d}$ when flavoured straw was not paired with casein and 92 (SEM 1.69) $\mathrm{g} / \mathrm{d}$ when flavoured straw was paired with casein.

Extinction. Our objective was to determine whether preferences acquired for flavoured straw during conditioning persisted when food ingestion was no longer paired with casein.

After completing each of the three conditioning periods and preference tests, casein administration was suspended and all lambs received only their basal diet every day during two consecutive periods of $7 \mathrm{~d}$ each (extinction periods 1 and 2). After each extinction period, preference tests were performed at 08.00 hours on two consecutive days. Lambs were offered maple- and anise-flavoured straw (150 g of each flavour) simultaneously for 20 min without casein administrations.

Casein dosing. Our objective was to determine whether administering high doses of casein after extinction diminished the preferences of lambs for flavoured straw.

The day after completing each extinction test, all lambs were offered the flavoured straw that had been eaten during casein administration. Immediately after beginning to eat the straw, a balling gun was used to administer gelatin capsules containing casein. After completing the period 1 and period 2 extinction tests, lambs received doses of casein that represented 0.69 and $1.38 \mathrm{~g} \mathrm{~N} / \mathrm{d}$ respectively. Preference tests were conducted the day after casein dosing, as described previously.

\section{Expt 4. Maize gluten and straw}

In this experiment we determined whether a protein with low rumen degradability (maize gluten), and consequently capable of altering the pattern of AA supply postruminally (Santos et al. 1984; Cecava et al. 1990), could condition preferences for flavoured wheat straw. All procedures of familiarization and conditioning were as described for Expt 1 . The flavours used in this trial were anise and maple (Agrimerica Inc.) and were mixed in the straw at $10 \mathrm{~g} / \mathrm{kg}$ concentration. During three conditioning periods, we gave to a new group 
of lambs, aged 3-4 months (19 kg BW) gluten to supply 0.23 (period 1), 0.46 (period 2), and $0.69 \mathrm{~g} \mathrm{~N}$ (period 3). Preference tests were conducted at the end of each conditioning period.

On average, lambs consumed 79 (SEM 3.33) g straw/d when flavoured straw was not paired with gluten and 84 (SEM 3.24) g/d when flavoured straw was paired with gluten. The lucerne pellets-barley $(55: 45, \mathrm{w} / \mathrm{w})$ basal diet $(840 \mathrm{~g} / \mathrm{d})$, straw and gluten $(0.23 \mathrm{~g} \mathrm{~N} / \mathrm{d})$ provided about $80 \%$ of the crude protein requirements of the lambs (National Research Council, 1985).

Extinction. After completing the three conditioning periods, extinction tests were conducted, after two extinction periods of $7 \mathrm{~d}$ each, as described for Expt 3.

\section{Chemical analyses}

Foods. Representative samples of lucerne pellets, barley, and wheat straw were collected, pooled and analysed for crude protein content (Hach et al. 1985). Lucerne pellets, barley and straw contained $25.9,17.9$ and $8.3 \mathrm{~g} \mathrm{~N} / \mathrm{kg}$ DM respectively.

Rumen determinations. For each experiment an additional group of four lambs received the same diets, $\mathbf{N}$ doses and conditioning schedule as that described previously. Samples of rumen contents were obtained through a stomach tube before and $0.5,1$ and $2 \mathrm{~h}$ after the $\mathrm{N}$ dose was administered. Rumen $\mathrm{pH}$ was measured and samples $(18 \mathrm{ml})$ of rumen contents were mixed with $2 \mathrm{ml} 6 \mathrm{M}-\mathrm{HCl}$, and prepared for rumen $\mathrm{NH}_{3}-\mathrm{N}$ determinations using Nessler's reagent (Association of Official Analytical Chemists, 1975).

\section{Statistical analyses}

Before conditioning. After random assignment of pairs of lambs to groups 1 or 2 , food intake during the initial preference test was analysed as a split-plot with animals nested within groups. Group was the between-subject factor and the treatment to be applied during the conditioning procedure was the within-subject factor in the split-plot analyses.

Preference tests. The statistical design for the analysis of variance during preference tests was a split-plot with animals nested within groups. Group ( 1 or 2$)$ was the betweensubject factor, and treatment ( $\mathrm{N} v$. no $\mathrm{N}$ ) during conditioning, day and period were the within-subject factors in the split-plot analyses.

Day and period were repeated measures. The treatment $\times$ group interaction was used to analyse for flavour effects. When there was a significant $(P<0.05)$ treatment $\times$ period interaction, means were compared using the least significant difference (LSD) test.

Rumen determinations. Values for $\mathrm{pH}$ and $\mathrm{NH}_{3}-\mathrm{N}$ concentrations were analysed in a split-plot design with lambs and amount of $\mathrm{N}$ as the whole plot; time of rumen contents extraction was the split-plot. When there was a significant $(P<0.05)$ treatment $\times$ time interaction, means were compared using the LSD test.

\section{RESULTS}

\section{Expt 1. Urea and straw}

Lambs did not display any differences in initial (i.e. before conditioning) preference for the flavours to be associated with urea $(5 v .7 \mathrm{~g}$ for treatments 1 and 2 respectively, SEM 1.7 ; $P>0.05)$. 
After period 1, when urea supplied $0.23 \mathrm{~g} \mathrm{~N} / \mathrm{d}$, lambs strongly avoided the flavour paired with urea ( 1 v. $19 \mathrm{~g} ; P<0.001$; Fig. 1). During period 2 , when the amount of urea was reduced to supply $0.12 \mathrm{~g} \mathrm{~N} / \mathrm{d}$, no preference was evident, but after period 3 , lambs developed a preference for the flavours associated with urea (45v. $31 \mathrm{~g} ; P<0.001$; Fig. 1 ), resulting in a treatment $\times$ period interaction $(P<0.001$; Fig. 1$)$.

Straw intake was low before conditioning (12 g), and during the first preference test $(20 \mathrm{~g})$, but increased gradually as conditioning periods progressed. Intake was highest after the last period of conditioning (period 3, 76 (SEM 3.0) g; $P<0.001$ ).

\section{Expt 2. urea and barley}

Before conditioning, lambs did not differ in their preference for the two flavours to be associated with urea (162 v. $161 \mathrm{~g}$ for treatments 1 and 2 respectively, SEM $26.7 \mathrm{~g}$; $P>0.05)$.

Lambs preferred the flavours paired with urea after the first $(0.23 \mathrm{~g} \mathrm{~N} / \mathrm{d} ; P<0.05$; Fig. 2) and third ( $0.46 \mathrm{~g} \mathrm{~N} / \mathrm{d} ; P<0.001 ;$ Fig. 2) conditioning periods (we cannot explain why preferences were not evident at the intermediate dose of $0.35 \mathrm{~g} \mathrm{~N} / \mathrm{d}$ in the second period). Conversely, lambs displayed a slight preference for the flavours not paired with urea when urea provided 0.92 (period 5$) \mathrm{g} \mathrm{N} / \mathrm{d}(P<0.05$; Fig. 2). This switch in preference across periods resulted in a treatment $\times$ period interaction $(P<0.001)$.

\section{Expt 3. casein and straw}

Before conditioning, lambs did not differ in their preference for the two flavours to be associated with casein $(50 v .46 \mathrm{~g}$ for treatments 1 and 2 respectively, SEM $6.2 \mathrm{~g} ; P>0.05)$.

Lambs preferred flavoured straw that was not paired with casein when the protein supplied $0.23 \mathrm{~g} \mathrm{~N} / \mathrm{d} ; P<0.001$; period 1 ), but their preference reversed when casein supplied 0.46 (period 2) or $0.69 \mathrm{~g} \mathrm{~N} / \mathrm{d}$ (period $3 ; P<0.05$; Fig. 3). This change in preference caused a treatment $\times$ period interaction $(P<0.05)$.

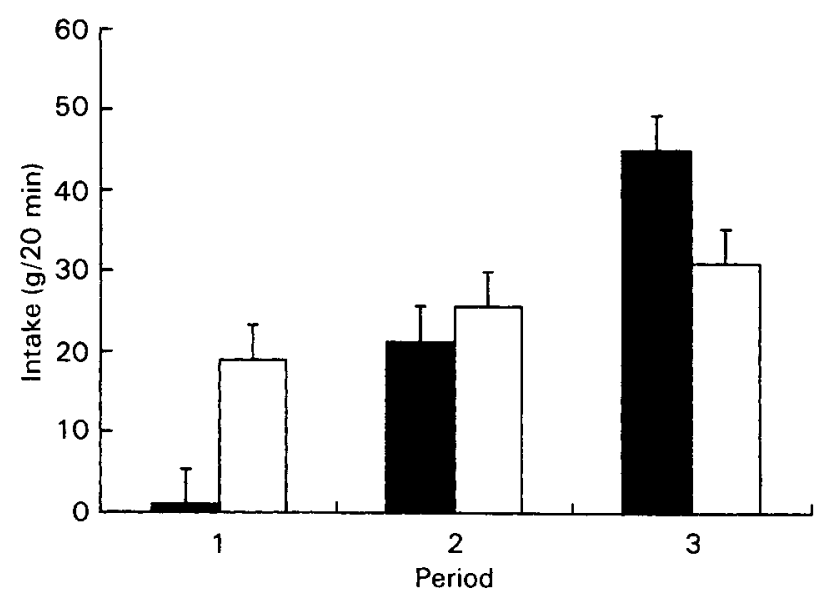

Fig 1. Expt 1. Mean intake of flavoured straw by lambs during three preference tests conducted after $8 \mathrm{~d}$ periods of conditioning with urea $(\square)$ providing 0.23 (period 1) and 0.12 (periods 2 and 3 ) g N/d on even-numbered days. Values are means with their standard errors represented by vertical bars. Mean values for periods 1 and 3 were significantly different from control values (no urea ( $\square$ ); $P<0.001$ ). For details of experimental procedures, see pp. 546-547. 


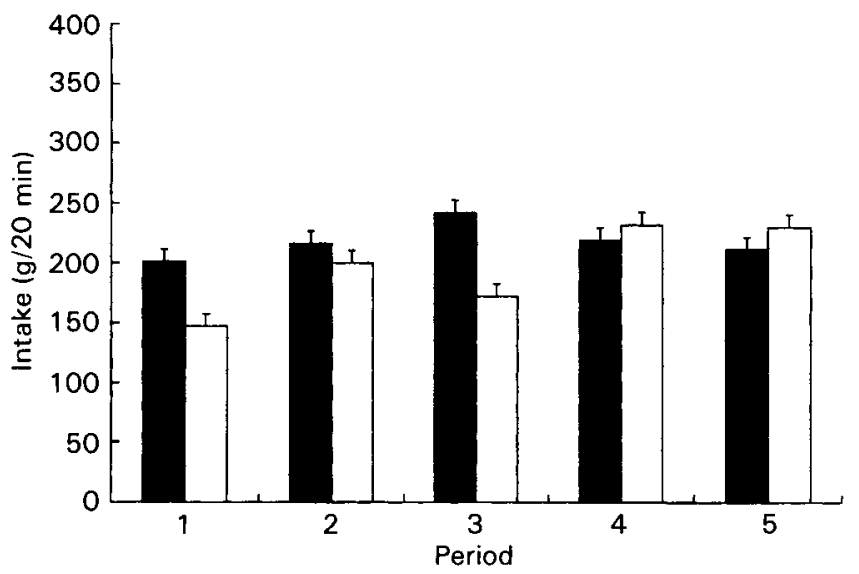

Fig 2. Expt 2. Mean intake of flavoured barley by lambs during five preference tests conducted after $8 \mathrm{~d}$ periods of conditioning with urea $(\square)$ providing 0.23 (period 1$), 0.35$ (period 2), $0.46($ period 3$), 0.69($ period 4$)$, and 0.92 (period 5) $\mathrm{g} \mathrm{N} / \mathrm{d}$ on even-numbered days. Values are means with their standard errors represented by vertical bars. Mean values for periods $1,3(P<0.001)$ and $5(P<0.05)$ were significantly different from control values (no urea $(\square)$ ). For details of experimental procedures, see pp. 547-548.

Consumption of the flavoured straw paired with casein was higher on the second day of testing than on the first day of testing after periods $1(53 v .46 \mathrm{~g}$, SEM $5.1 \mathrm{~g} ; P<0 \cdot 09)$ and 3 (62 v. $53 \mathrm{~g}$, SEM $5.3 \mathrm{~g}, P<0.05$ ). Conversely, consumption of the flavoured straw not associated with casein was lower on the second day of testing than on the first day of testing in all three periods (period 1, $55 v .63 \mathrm{~g}$, SEM $5.0 \mathrm{~g} ; P<0.06$; period 2, $44 v .53 \mathrm{~g}$, SEM $5.1 \mathrm{~g} ; P<0.05$; period 3, 46 v. $53 \mathrm{~g}$; SEM $5.3 \mathrm{~g} ; P<0.09$ ).

Extinction. Lambs retained preferences for flavours paired with casein after cessation of casein conditioning $(P<0.001$; Fig. 4).

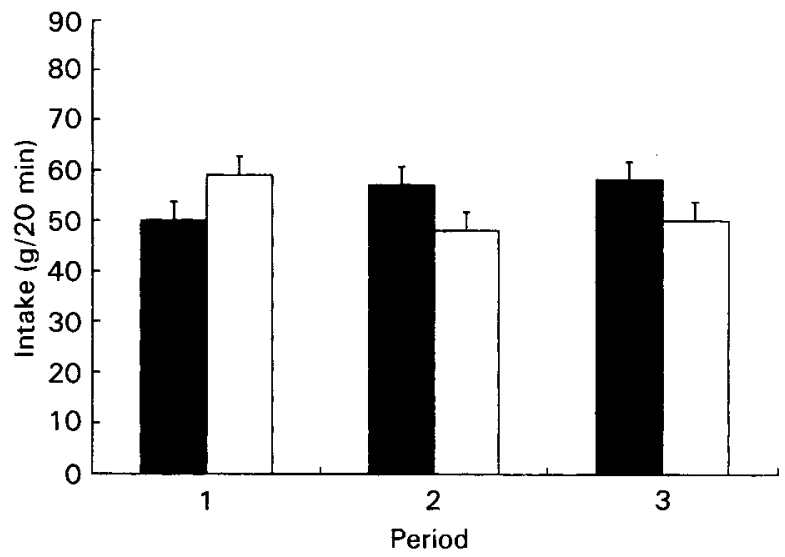

Fig. 3. Expt 3. Mean intake of flavoured straw by lambs during three preference tests conducted after $8 \mathrm{~d}$ periods of conditioning with casein ( $\square$ ) providing 0.23 (period 1), 0.46 (period 2), and 0.69 (period 3 ) $\mathrm{g} \mathrm{N} / \mathrm{d}$ on even days. Values are means with their standard errors represented by vertical bars. Mean values for periods $1(P<0.001), 2$ and 3 $(P<0.05)$ were significantly different from control values (no casein $(\square)$ ). For details of experimental procedures, see p. 548 . 


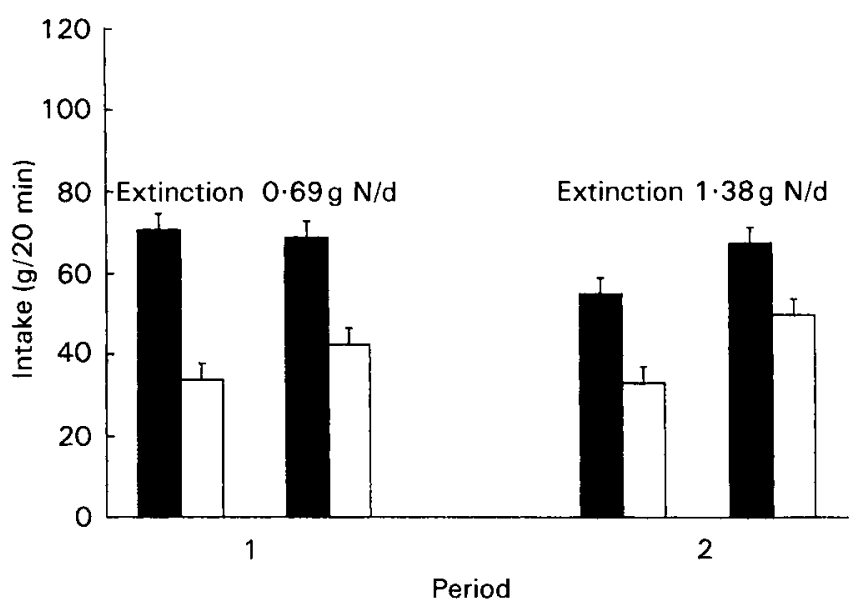

Fig. 4. Expt 3. Mean intake of flavoured straw by lambs after conditioning with casein ( $\square$ ); extinction), and following casein doses ( $\boldsymbol{G}$ ) of 0.69 and $1.38 \mathrm{~g} \mathrm{~N} / \mathrm{d}$. Values are means with their standard errors represented by vertical bars. Mean values in all periods were significantly different from control values (no casein $(\square) ; P<0.001$ ). For details of experimental procedures, see p. 548.

Lambs preferred maple to anise (pooled means across periods $63 v .43 \mathrm{~g}$, SEM $4.59 \mathrm{~g}$ ) during extinction, as shown by a group $\times$ treatment interaction $(P<0.001)$. Nevertheless, casein conditioned an increase in intake of anise (from $29 \mathrm{~g}$ without casein to $54 \mathrm{~g}$ with casein) and maple (from $39 \mathrm{~g}$ without casein to $71 \mathrm{~g}$ with casein; pooled means across periods, $P<0.001$ ).

Casein dosing. Intake of flavours not associated with casein increased from $34 \mathrm{~g}$ (extinction) to $42 \mathrm{~g}$ (SEM $3.70 \mathrm{~g} ; P<0.05$; Fig. 4) after the first dose of casein $(0.69 \mathrm{~g} \mathrm{~N} /$ d). Intake of both flavours increased after the second dose of casein (1.38 g N; Fig. 4), but the increase was lower for flavours associated with casein $(P<0.07$; Fig. 4). Both these findings suggest that preference for flavours conditioned with casein diminished immediately after a dose of casein.

\section{Expt 4. Maize gluten and straw}

Before conditioning, lambs did not differ in their preference for the flavours to be associated with gluten ( $40 v .41 \mathrm{~g}$ for treatments 1 and 2 respectively, SEM $5.5 \mathrm{~g} ; P>0.05$ ).

Lambs displayed a slight preference for flavoured straw not paired with gluten $(0.23 \mathrm{~g} \mathrm{~N} / \mathrm{d})$ after the first period of conditioning $(P<0.05$; Fig. 5$)$. When the amount of gluten was increased to supply $0.46 \mathrm{~g} \mathrm{~N} / \mathrm{d}$ (period 2) and $0.69 \mathrm{~g} \mathrm{~N} / \mathrm{d}$ (period 3), lambs preferred the flavours paired with gluten $(P<0.05$ and $P<0.001$ respectively; Fig. 5), which caused a treatment $\times$ period interaction $(P<0.001)$. Total straw intake during preference tests was higher for period 3 than for periods 1 and $2(60 v .43$ and $42 \mathrm{~g}$ respectively, SEM $2.68 ; P<0.001$ ).

Lambs preferred maple to anise (pooled means across periods $59 v .38 \mathrm{~g}$, SEM $4.58 \mathrm{~g}$ ), which resulted in a treatment $\times$ group interaction $(P<0.001)$. Preference for aniseflavoured straw increased from 31 to $44 \mathrm{~g}$, whereas preference for maple-flavoured straw increased from 51 to $67 \mathrm{~g}$ when these flavours were associated with gluten (pooled means across periods, SEM $6.33 ; P<0.001$ ).

Extinction. Lambs retained their preferences for the flavours paired with gluten for 2 weeks $(P=0.06$; Fig. 6). Anise and maple flavours were consumed in similar amounts 


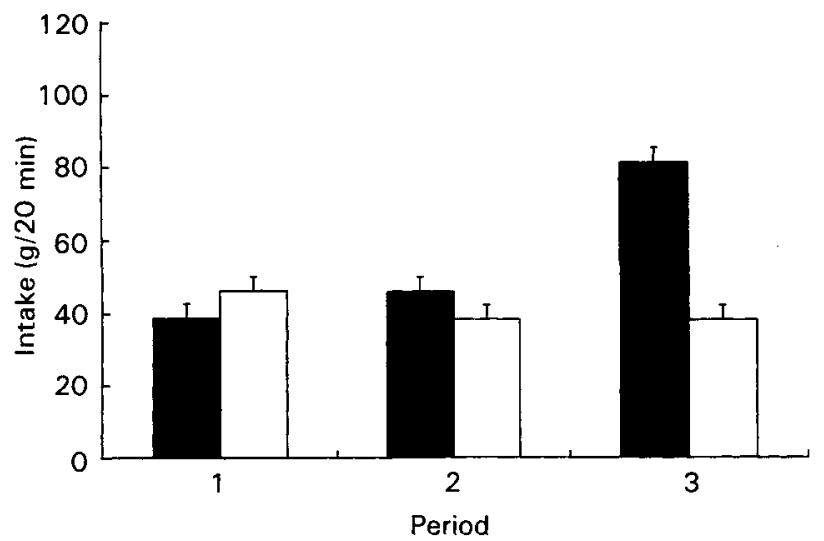

Fig. 5. Expt 4. Mean intake of flavoured straw by lambs during three preference tests conducted after $8 \mathrm{~d}$ periods of conditioning with gluten ( $\square$ ) providing 0.23 (period 1), 0.46 (period 2), and 0.69 (period 3 ) g N/d on even-numbered days. Values are means with their standard errors represented by vertical bars. Mean values for periods 1 and 2 $(P<0.05)$, and $3(P<0.001)$ were significantly different from control values (no gluten $(\square)$ ). For details of experimental procedures, see pp. 548-549.

during extinction (pooled means across periods 52 v. $59 \mathrm{~g}$ respectively, SEM 7.39; $P>0.05)$.

\section{Rumen determinations}

pH measurements. Rumen $\mathrm{pH}$ values did not change with time or with dose of $\mathrm{N}$ $(P>0.05)$. They were approximately neutral in Expts 1,3 and 4 (Table 1$)$.

Rumen $\mathrm{pH}$ decreased with time for some doses of urea (i.e. $0.23,0.35$ and $0.92 \mathrm{~g} \mathrm{~N} / \mathrm{d}$; Table 1$)$ in Expt 2, which caused a treatment $\times$ time interaction $(P<0.05)$. Nevertheless, values were approximately neutral, so acidity associated with barley consumption or

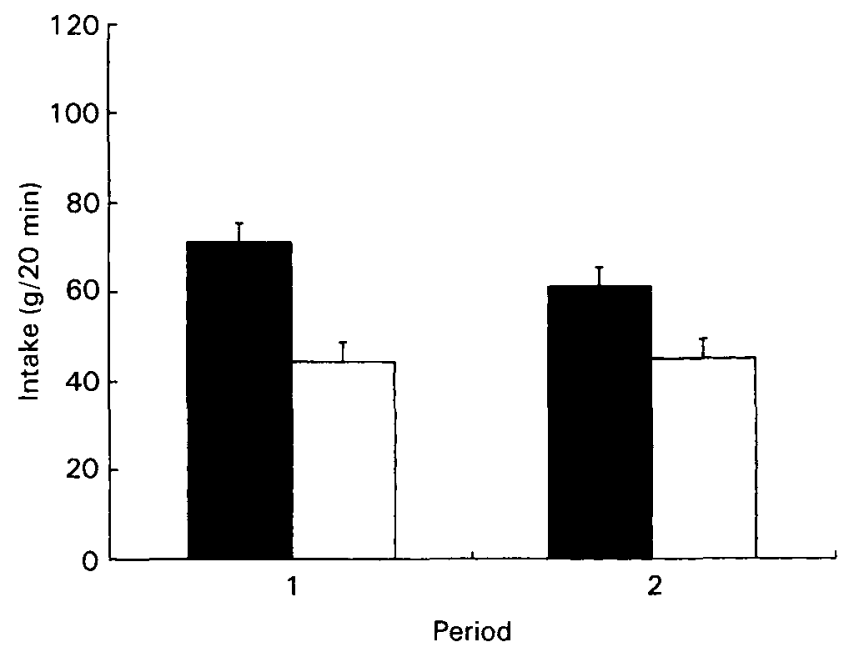

Fig. 6. Expt 4. Mean intake of flavoured straw by lambs after conditioning with gluten ( $\boldsymbol{\square}$; extinction). Values are means with their standard errors represented by vertical bars. Mean values in all periods were significantly different from control values (no gluten $(\square) ; P=0.06$ ). For details of experimental procedures, see pp. 548-549. 
Table 1. $p H$ and ammonia-nitrogen $(m g /)$ in rumen contents of four lambs before and after intraruminal administrations of nitrogen in different forms*

\begin{tabular}{|c|c|c|c|c|c|c|c|}
\hline \multirow[b]{2}{*}{ Expt no. } & \multirow[b]{2}{*}{ Form of $\mathbf{N}$} & \multirow[b]{2}{*}{ Amount of $N(g / d)$} & \multicolumn{4}{|c|}{ Time interval after the administration (h): } & \multirow[b]{2}{*}{ SEM } \\
\hline & & & 0 & 0.5 & 1 & 2 & \\
\hline \multicolumn{8}{|l|}{$\mathrm{pH}$} \\
\hline \multirow[t]{2}{*}{1} & Urea & 0.12 & $6 \cdot 8$ & $6 \cdot 9$ & 6.8 & 6.8 & $0 \cdot 17$ \\
\hline & & 0.23 & $6 \cdot 8$ & $7 \cdot 0$ & 6.9 & $7 \cdot 1$ & \\
\hline \multirow[t]{6}{*}{2} & Urea & 0 & $6 \cdot 7^{\mathrm{a}}$ & $6.8^{a}$ & $6 \cdot 8^{\mathrm{a}}$ & $6 \cdot 9^{b}$ & 0.08 \\
\hline & & 0.23 & $7 \cdot 1^{\mathbf{a}}$ & $6.8^{b}$ & $6 \cdot 6^{c}$ & $6 \cdot 6^{\mathrm{c}}$ & \\
\hline & & 0.35 & $7 \cdot 3^{\mathrm{a}}$ & $6 \cdot 9^{b}$ & $6 \cdot 8^{\mathrm{c}}$ & $6 \cdot 7^{\mathrm{c}}$ & \\
\hline & & 0.46 & $7 \cdot 0$ & $6 \cdot 9$ & 6.9 & 6.9 & \\
\hline & & 0.69 & $7 \cdot 2$ & $7 \cdot 1$ & $7 \cdot 1$ & 7.2 & \\
\hline & & 0.92 & $7 \cdot 4^{\mathrm{a}}$ & $7 \cdot 2^{b}$ & $7 \cdot 1^{\mathrm{b}}$ & $7 \cdot 1^{\mathrm{b}}$ & \\
\hline \multirow[t]{3}{*}{3} & Casein & 0.23 & $6 \cdot 6$ & 6.7 & 6.8 & 6.7 & 0.17 \\
\hline & & 0.46 & 6.9 & $6 \cdot 9$ & 6.8 & 6.9 & \\
\hline & & 0.69 & 7.0 & 7.0 & 6.8 & 6.9 & \\
\hline \multirow[t]{3}{*}{4} & Gluten & 0.23 & $7 \cdot 1$ & $7 \cdot 3$ & $7 \cdot 1$ & 7.0 & 0.15 \\
\hline & & 0.46 & $7 \cdot 1$ & 7.0 & 7.0 & $7 \cdot 1$ & \\
\hline & & 0.69 & 6.9 & $6 \cdot 9$ & 7.0 & 7.2 & \\
\hline $1,3,4$ & Control & 0 & $6 \cdot 9$ & 6.7 & $7 \cdot 2$ & $6 \cdot 8$ & \\
\hline \multicolumn{8}{|l|}{$\mathrm{NH}_{3}-\mathrm{N}$} \\
\hline \multirow[t]{2}{*}{1} & Urea & 0.12 & 113 & 130 & 126 & 122 & $15 \cdot 8$ \\
\hline & & 0.23 & 93 & 130 & 130 & 129 & \\
\hline \multirow[t]{6}{*}{2} & Urea & 0 & 84 & 81 & 70 & 72 & $15 \cdot 1$ \\
\hline & & 0.23 & $82^{a}$ & $152^{\mathbf{b}}$ & $135^{\mathrm{c}}$ & $75^{a}$ & \\
\hline & & 0.35 & $113^{a}$ & $178^{b}$ & $151^{\mathrm{c}}$ & $77^{d}$ & \\
\hline & & 0.46 & $75^{\mathrm{a}}$ & $131^{b}$ & $138^{\mathrm{b}}$ & $83^{a}$ & \\
\hline & & 0.69 & $97^{\mathrm{a}}$ & $192^{b}$ & $160^{c}$ & $97^{a}$ & \\
\hline & & 0.92 & $102^{a}$ & $289^{b}$ & $257^{\mathrm{c}}$ & $155^{\mathrm{d}}$ & \\
\hline \multirow[t]{3}{*}{3} & Casein & 0.23 & 127 & 122 & 146 & 136 & $13 \cdot 8$ \\
\hline & & 0.46 & 81 & 97 & 124 & 107 & \\
\hline & & 0.69 & 98 & 120 & 170 & 150 & \\
\hline \multirow[t]{3}{*}{4} & Gluten & 0.23 & 105 & 101 & 107 & 110 & 13.5 \\
\hline & & 0.46 & 107 & 105 & 126 & 124 & \\
\hline & & 0.69 & 78 & 84 & 101 & 101 & \\
\hline $1,3,4$ & Control & 0 & 107 & 107 & 114 & 95 & \\
\hline
\end{tabular}

a,b,c,d Means within a row with unlike superscript letters were significantly different $(P<0.05)$.

* For details of experimental procedures, see pp. 546-549.

alkalinity associated with urea infusions probably did not influence preference or food intake (Table 1).

$\mathrm{NH}_{3}-\mathrm{N}$ measurements. $\mathrm{NH}_{3}-\mathrm{N}$ concentration was not affected by the level of urea administered in Expt 1, and $\mathrm{NH}_{3}-\mathrm{N}$ values did not change with time $(P>0.05$; Table 1$)$. However, average $\mathrm{NH}_{3}-\mathrm{N}$ levels were about $15 \%$ higher with 0.12 and $0.23 \mathrm{~g} \mathrm{~N} / \mathrm{d}$ than without urea. Urea supply increased rumen $\mathrm{NH}_{3}-\mathrm{N}$ in Expt $2(P<0.001$; Table 1$)$ in comparison with the control $(0 \mathrm{~g} \mathrm{~N} / \mathrm{d})$. $\mathrm{NH}_{3}-\mathrm{N}$ concentration increased after urea administrations $(P<0.05$; Table 1$)$, and there was a treatment $\times$ time interaction $(P<0.001)$. When casein supplied 0.23 and $0.69 \mathrm{~g} \mathrm{~N} / \mathrm{d}, \mathrm{NH}_{3}-\mathrm{N}$ levels tended to be higher than when no casein was administered $(0 \mathrm{~g} \mathrm{~N} / \mathrm{d} ; P=0 \cdot 12)$, and average $\mathrm{NH}_{3}-\mathrm{N}$ concentrations increased after 1 and $2 \mathrm{~h}$ of casein supply in comparison with 0 and $0.5 \mathrm{~h}$ $(P<0.05)$. $\mathrm{NH}_{3}-\mathrm{N}$ was not affected by the different doses of gluten, and $\mathrm{NH}_{3}-\mathrm{N}$ concentrations did not change with time $(P>0.05)$. 


\section{DISCUSSION}

\section{Aversions}

Urea. Lambs in our studies formed aversions to lower levels of urea than typically considered to influence food intake (Wilson et al. 1975). Two possible reasons for the effect of low levels of urea on intake are: first, the two-choice tests we used to assess preference are more sensitive in detecting negative effects on intake promoted by excesses of nutrients than single-food trials; second, we administered urea in Expt 1 along with a food that was low in readily-fermentable carbohydrates (i.e. wheat straw), which did not promote efficient capture by microbes of rumen-degradable $\mathrm{N}$, and in turn probably enhanced the negative post-ingestive effects of urea $\left(\mathrm{NH}_{3}\right)$.

Lambs in Expts 1 and 2 avoided the flavour paired with the highest doses of urea (Figs. 1 and 2). This response probably resulted from the rapid hydrolysis of urea to $\mathrm{NH}_{3}$ in the rumen, which may have induced aversive post-ingestive feedback (Kertz et al. 1982; Provenza, 1996). Sheep avoid an excess of urea in their diet (Kyriazakis \& Oldham, 1993; Oldham, 1993) because high levels of urea can cause subclinical $\mathrm{NH}_{3}$ toxicity (Chalupa $e t$ al. 1970; Prior et al. 1970; Fernandez et al. 1990), which depresses food intake (Wilson et al. 1975; Kertz et al. 1982). The negative effects of $\mathrm{NH}_{3}$ on food intake are not completely understood, but they may involve peripheral (Visek, 1968) and central (Felipo et al. 1993) mechanisms mediated by increased plasma levels of $\mathrm{NH}_{3}$ (Mugerwa \& Conrad, 1971). Sheep regulate intake of foods with high levels of non-protein- $\mathrm{N}$ to maintain blood $\mathrm{NH}_{3}-\mathrm{N}$ levels below $2 \mathrm{mg} / \mathrm{l}$ (Nicholson et al. 1992).

Urea administration did not significantly increase rumen $\mathrm{NH}_{3}-\mathrm{N}$ concentrations in Expt 1 (Table 1), but average $\mathrm{NH}_{3}-\mathrm{N}$ values were $15 \%$ higher with urea. The method of urea administration (by capsules) probably led to higher concentrations of urea at particular locations in the rumen, and probably enhanced the negative effects of $\mathrm{NH}_{3}$, even though lambs simultaneously ingested a source of fermentable carbohydrates in Expt 2 . Some authors claim modulation of urea intake is related to its undesirable taste (e.g. Huber \& Cook, 1972), but our results support earlier work, which suggests the post-ingestive action of urea is the main cause of avoidance of urea-containing diets (Wilson et al. 1975; Kertz et al. 1982).

Casein. Preference for the flavours associated with casein was lower for the first day than for the second day of preference testing. Casein is rapidly degraded to $\mathrm{NH}_{3}$ in the rumen (Kempton et al. 1979) and rumen $\mathrm{NH}_{3}-\mathrm{N}$ concentrations tended to increase with casein administrations (Table 1). Consequently, casein probably attenuated preferences through the production of $\mathrm{NH}_{3}$ (Fig. 3). Delivering casein after extinction increased preferences for flavours not associated with the protein (Fig. 4), which supports the hypothesis that some action of casein (probably $\mathrm{NH}_{3}$ formation) diminished preference. This response was not evident in Expt 4, where the low degradability of gluten in the rumen did not change rumen $\mathrm{NH}_{3}-\mathrm{N}$ concentrations (Table 1).

\section{Preferences}

Lambs formed preferences for flavours associated with supplemental sources of $\mathrm{N}$ (Expts 1-4).

Urea. In Expt 1, lambs acquired a preference for the flavour paired with urea and increased straw intake when urea supplied only $0.12 \mathrm{~g} \mathrm{~N} / \mathrm{d}$ (Fig. 1). Urea supplementation can increase intake of poor-quality foods (Hemsley \& Moir, 1963; Umunna, 1982). The increase in intake has been attributed to a more rapid clearance of food from the reticulorumen, which is promoted by the increased availability of $\mathrm{N}$ to rumen micro-organisms. 
Intraruminal infusions of urea also stimulate intake by increasing the supply of microbial protein to the intestines (Egan \& Doyle, 1985). In our study, lambs did not receive urea during preference tests. Nonetheless, preference increased after flavours were paired with urea. Thus, the post-ingestive effects of urea (i.e. the increased $\mathrm{N}$ supply to the host), and not rumen limitations, apparently caused the increase in preference.

Lambs preferred the flavours paired with higher doses of urea when straw was replaced with barley (Expt 2; Fig. 2). Synchronizing the supply of urea with a rapidly-degraded source of energy probably improved the utilization of urea. $\mathrm{N}$ balance and efficiency of $\mathrm{N}$ utilization tend to be optimal when lambs fed on barley are supplemented with urea (Matras et al. 1991). Balancing the supply of fermentable carbohydrates and $\mathrm{N}$ optimizes microbial protein synthesis and maximizes the retention of rumen-degradable $\mathrm{N}$ (Sinclair $e t$ al. 1993). Conversely, when the rate of $\mathrm{NH}_{3}$ formation exceeds the rate of carbohydrate fermentation (for example, as probably occurred in Expt 1), $\mathrm{N}$ is used inefficiently by microbes, and a large proportion of $\mathrm{N}$ is lost as $\mathrm{NH}_{3}$ in urine (Russell et al. 1992; Huber \& Herrera-Saldana, 1994).

Casein. Lambs preferred flavoured straw associated with casein after periods 2 and 3 (Fig. 3). Supplementation with casein increases roughage intake by sheep (Egan, 1970; Kempton \& Leng, 1979). Ingestion of low-quality diets either alone or supplemented with non-protein sources of $\mathrm{N}$ such as urea may limit the provision of AA to rumen microorganisms and, thus, reduce microbial yield (Ørskov, 1982). Some authors attribute the effect of casein to enhanced provision of AA to rumen microbes, which in turn increases rumen clearance (e.g. due to an increased cellulose digestion) and microbial yield (for example, see Redman et al. 1980). Other authors attribute the action of casein to a chemoregulatory mechanism linked to the improved protein status after casein ingestion (Egan \& Moir, 1964; Egan, 1970, 1980). In our study, alleviation of rumen fill was certainly not the main effect of casein because lambs consumed only an average of $92 \mathrm{~g}$ flavoured straw/d during casein conditioning. Rather, we submit that brief increases in microbial yield (former hypothesis) combined with increases in protein supply to the host (latter hypothesis) probably caused the development of food preference in our study.

Gluten. By infusing gluten, a protein with low rumen degradability, we provided additional protein for direct digestion in the intestines. Lambs developed a preference for the flavours paired with gluten infusions after the second and third periods of conditioning. Feeding protein sources resistant to rumen degradation alters AA supply postruminally (Santos et al. 1984; Cecava et al. 1990), which in turn increases food intake (Egan \& Moir, 1964; Egan, 1965) and animal performance (Clark et al. 1987; Willms et al. 1991).

Ruminants cannot synthesize essential AA so they must rely on microbial and undegraded dietary protein to satisfy their requirements (Owens, 1988). The AA composition of microbial protein is relatively constant (Storm \& Ørskov, 1983) and may be limiting in AA like methionine for optimal animal production (Storm \& Ørskov, 1984; Merchen \& Titgemeyer, 1992). Intraperitoneal (Barry, 1976) or intravenous (Forbes, 1995) infusions of methionine cause sheep to increase intake of low- $\mathrm{N}$ diets. These results support the hypothesis that ruminants can sense AA imbalances, as can non-ruminants (e.g. Gietzen, 1993). Likewise, lambs decrease intake of foods associated with AA deficiencies, and increase intake when the deficiency is rectified (Rogers \& Egan, 1975; Egan \& Rogers, 1978).

In our study, an improvement in the profile of AA supply to the intestines may have provided feedback signals that conditioned preferences. Maize gluten is an important source of essential and non-essential AA (Merchen \& Titgemeyer, 1992); it provides especially high quantities of methionine, histidine, and arginine (Clark et al. 1987; 
Merchen \& Titgemeyer, 1992), AA that are limiting in rumen microbial protein (Storm \& Ørskov, 1984).

\section{Continuum aversions-preferences}

Our studies (i.e. Expts 1 and 2) show that lambs modified their choice for flavoured food from an aversion (e.g. with doses of $0.23 \mathrm{~g} \mathrm{~N} / \mathrm{d}$ in Expt 1 or $0.92 \mathrm{~g} \mathrm{~N} / \mathrm{d}$ in Expt 2) to a preference (e.g. doses of $0.12 \mathrm{~g} \mathrm{~N} / \mathrm{d}$ in Expt 1 or 0.23 and $0.35 \mathrm{~g} \mathrm{~N} / \mathrm{d}$ in Expt 2), depending on the dose of urea administered. This finding is consistent with previous studies showing that ruminants change their intake of urea depending on physiological requirement and dietary characteristics. Cattle, buffalo and sheep adjust intake of molasses-urea blocks in direct accordance with the $\mathrm{N}$ content of the basal diet: low levels of dietary $\mathrm{N}$ promote the highest intake of molasses-urea blocks and vice versa (for review, see Leng, 1990). Casein doses also diminished preferences temporarily (Fig. 4). Collectively, these results support the hypothesis that food preferences and aversions reside along a continuum where either of these states can be conditioned by nutrients depending on an animal's requirements and the amounts and/or rates of nutrient supply (Provenza, 1995a, 1996).

\section{Physiological condition}

Different conclusions have been drawn regarding the importance of $\mathrm{N}$ in diet selection. Some authors contend large herbivores maximize rate of protein intake (for example Belovsky, 1984; Langvatn \& Hanley, 1993), whereas other authors claim they maximize energy intake (for example Wilmshurst et al. 1995), or simply that dietary choices are not influenced by the protein content of the food (for example Coppock et al. 1974; Zahorik \& Houpt, 1977). Other authors conclude that sheep can discriminate between forages differing in $\mathrm{N}$ and fibre content, but cannot modify their foraging behaviour in relation to the levels of supplementary protein received before grazing (Duncan et al. 1994). This disparity may occur because $\mathbf{N}$ is only one of the post-ingestive signals affecting food preference (MacRae \& Lobley, 1988; Villalba \& Provenza, 1996, 1997), and because of differences in the physiological state of the animal.

Preference for particular nutrients depends on nutritional requirements (Mook, 1988; Scott, 1990; Booth, 1991). Preference increases when nutrients ameliorate needs, and decreases when they satiate needs (Provenza, 1995a,b). Thus, the importance of $\mathrm{N}$ on dietary choices depends on the physiological condition of the animal. Learned preference for $\mathrm{N}$ depends on physiological requirement in rats (Gibson \& Booth, 1986; Baker et al. 1987; Booth, 1991), and in human subjects (Wurtman \& Wurtman, 1986; Noach, 1994). Protein status also affects intake of low-protein roughages (Egan \& Moir, 1964; Egan, 1970, 1980), and food selection in sheep (Cooper et al. 1993, Kyriazakis et al. 1994). In our study, lambs ingested no more than $80 \%$ of their required crude protein, which undoubtedly enhanced their sensitivity to $\mathrm{N}$, and consequently strengthened the development of preferences for flavours associated with supplemental sources of $\mathrm{N}$.

Often, the chemical composition of plants has been correlated with diet selection in an attempt to understand the food preferences of ruminants (for example, see Cowlishaw \& Alder, 1960; Langvatn \& Hanley, 1993; Duncan et al. 1994; Wilmshurst et al. 1995). In addition to the fact that correlation does not imply causation (Romesburg, 1981), it is impossible using that methodology to assess the importance of isolated nutrients (e.g. protein) on food preference. In our study, animals received the same basal diet, and ingested similar amounts of a test food (straw, barley) during conditioning. Thus, we controlled for flavour exposure, flavour preference, and rumen conditions. Under these 
conditions, lambs preferred flavoured foods paired with $\mathrm{N}$ administered in different forms. These results support the hypothesis that $\mathrm{N}$ is a post-ingestive feedback signal that affects food preference.

\section{Extinction}

Lambs preferred the flavour paired with casein, even after conditioning (Fig. 4). While the negative effects of $\mathrm{NH}_{3}$ may have attenuated preference for casein during conditioning, the sustained requirement for $\mathrm{N}$ in a $\mathrm{N}$-deficient diet (i.e. animals received only $80 \%$ of their crude protein requirements) may have enhanced preferences for casein during extinction. Preferences for flavours associated with casein were more evident during extinction than during all three periods of conditioning (Figs. 3 and 4). If $\mathrm{NH}_{3}$ induced gastrointestinal discomfort during the periods where low preferences for urea and casein were found, it is possible that a temporary improvement in $\mathrm{N}$ status achieved by an increased supply of urea or casein was more important in driving flavour preference than $\mathrm{NH}_{3}$ formation. Thus, urea and casein probably have a dual action. While excesses may temporarily depress preference through the negative actions of $\mathrm{NH}_{3}$, they may also enhance preference through their contributions to the $\mathrm{N}$ metabolism of the animal.

Lambs also retained their preferences for the flavours paired with gluten, but the response diminished with time in the absence of gluten administration (Fig. 5). Lambs also retain learned preferences for flavoured straw paired with starch (Villalba \& Provenza, 1997) and sodium propionate (Villalba \& Provenza, 1996). Thus, nutrient feedback may increase the hedonic value of foods (i.e. liking the flavour of the food), such that preference for flavour becomes resistant to extinction, as in non-ruminants (Mehiel, 1991).

\section{CONCLUSIONS}

We demonstrated that lambs acquire preferences and aversions for flavours paired with different amounts and forms of N. Preferences persisted when protein (i.e. casein, gluten) was no longer administered. Thus, post-ingestive feedback from $\mathbf{N}$ can modify dietary choices by sheep.

Some claim that ruminants adjust their intake according to a preferred physiological state associated with an adequate protein:energy value (Egan, 1977, 1980; Leng, 1990). Recent research has shown that growing sheep select from isoenergetic foods differing in protein density, a diet with a constant amount of crude protein $/ \mathrm{kg} \mathrm{DM}$ (Hou et al. 1991; Provenza et al. 1996) that maximizes growth rate (Kyriazakis \& Oldham, 1993).

In previous studies (Villalba \& Provenza, 1996, 1997), we demonstrated that energyrestricted sheep (ingesting $80 \%$ of their required digestible energy) acquire preferences for a low-quality food (straw) paired with energy sources (e.g. starch, propionate), and we have now demonstrated that $\mathrm{N}$-restricted sheep form preferences for a low-quality food when it is associated with $\mathbf{N}$ administration. Thus, it is possible that sheep adjust preference and intake as a function of their physiological state relative to the chemical characteristics of a food (Provenza, 1995b).

The multi-dimensionality of sensory stimuli experienced by ruminants before, during, and after eating, suggests that the process of diet selection is an integrated response to more than one stimulus. Food flavour and nutrient content (e.g. carbohydrates, protein) are some of the stimuli on which diet selection is based.

This research was supported by grants from the Cooperative States Research Service and the Utah Agricultural Experimental Station. This paper is published with the approval of the Director, Utah Agriculture Experimental Station, Utah State University, as Journal 
paper no. 3940. J.J.V. is grateful for the additional financial support received from the Consejo Nacional de Investigaciones Científicas y Técnicas (CONICET), Argentina.

\section{REFERENCES}

Association of Official Analytical Chemists. (1975). Official Methods of Analysis, 12th ed. Washington, DC: AOAC.

Baker, B. J., Booth, D. A., Dugan, J. P. \& Gibson, E. L. (1987). Protein appetite demonstrated: learned specificity of protein-cue preference to protein need in adult rats. Nutrition Research 7, 481-487.

Barry, T.N. (1976). Effects of intraperitoneal injections of DL-methionine on the voluntary intake and wool growth of sheep fed sole diets of hay, silage and pasture differing in digestibility. Journal of Agricultural Science, Cambridge 86, 141-149.

Belovsky, G.E. (1984). Herbivore optimal foraging: a comparative test of three models. American Naturalist $124,97-115$.

Booth, D. A. (1991). Protein- and carbohydrate-specific cravings: neuroscience and sociology. In Chemical Senses, Vol. 4. Appetite and Nutrition, pp. 261-276 [M. I. Friedman, M. G. Tordoff and M. R. Kare, editors]. New York: Marcel Dekker Inc.

Burritt, E. A. \& Provenza, F.D. (1992). Lambs form preferences for nonnutritive flavors paired with glucose. Journal of Animal Science 70, 1133-1136.

Cecava, M.J., Merchen, N. R., Berger, L. L., \& Fahey, G. C. Jr (1990). Intestinal supply of amino acids in sheep fed alkaline hydrogen peroxide-treated wheat straw-based diets supplemented with soybean meal or combinations of corn gluten meal and blood meal. Journal of Animal Science 68, $467-477$.

Chalupa, W., Clark, J., Opliger, P. \& Lavker, R. (1970). Detoxification of ammonia in sheep fed soy protein or urea. Journal of Nutrition 100, 170-176.

Clark, J.H., Murphy, M.R. \& Crooker, B. A. (1987). Symposium: Alternate feed sources for dairy cattle. Journal of Dairy Science 70, 1092-1109.

Cooper, S. D. B., Kyriazakis, I., Anderson, D. H. \& Oldham, J. D. (1993). The effect on physiological state (late pregnancy) on the diet selection of ewes. Animal Production 56, 469A.

Coppock, C. E., Everett, R. W., Smith, N. E., Slack, S. T. \& Harner, J. P. (1974). Variation in forage preference in dairy cattle. Journal of Animal Science 39, 1170-1179.

Cowlishaw, S. J. \& Alder, F.E. (1960). The grazing preferences of cattle and sheep. Journal of Agricultural Science, Cambridge 54, 257-265.

Duncan, A. J., Hartley, S. E. \& Iason, G. R. (1994). Fine-scale discrimination of forage quality by sheep offered a soyabean mean or barley supplement while grazing a nitrogen-fertilized heather (Calluna vulgaris) mosaic. Journal of Agricultural Science, Cambridge, 123, 363-370.

Egan, A.R. (1965). Nutritional status and intake regulation in sheep. II. The influence of sustained duodenal infusions of casein or urea upon voluntary intake of low-protein roughages by sheep. Australian Journal of Agricultural Research 16, 451-462.

Egan, A. R. (1970). Nutritional status and intake regulation in sheep. VI. Evidence for variation in setting of an intake regulatory mechanism relating to the digesta content of the reticulorumen. Australian Journal of Agricultural Research 21, 735-746.

Egan, A. R. (1977). Nutritional status and intake regulation in sheep. VIII. Relationships between the voluntary intake of herbage by sheep and the protein/energy ratio in the digestion products. Australian Journal of Agricultural Research 28, 907-915.

Egan, A.R. (1980). Host animal-rumen relationships. Proceedings of the Nutrition Society 39, 79-87.

Egan, A. R. \& Doyle, P. T. (1985). Effect of intranuminal infusion of urea on the response in voluntary food intake by sheep. Australian Journal of Agricultural Research 36, 483-495.

Egan, A. R. \& Moir, R. J. (1964). Nutritional status and intake regulation in sheep. I. Effects of duodenally infused single doses of casein, urea, and propionate upon voluntary intake of a low-protein roughage by sheep. Australian Journal of Agricultural Research 16, 437-449.

Egan, A.R. \& Rogers, Q.R. (1978). Amino acid imbalance in ruminant lambs. Australian Journal of Agricultural Research 29, 1263-1279.

Felipo, V., Grau, E., Minana, M.D. \& Grisolia, S. (1993). Ammonium injection induces an N-methyl-Daspartate receptor-mediated proteolysis of the microtubule-associated protein MAP-2. Journal of Neurochemistry 60, 1626-1630.

Fernandez, J. M., Croom, W. J. Jr., Tate, L. P., Jr. \& Johnson, A. D. (1990). Subclinical ammonia toxicity in steers: effects on hepatic and portal-drained visceral flux of metabolites and regulatory hormones. Journal of Animal Science 68, 1726-1742.

Forbes, J.M. (1995). Voluntary Food Intake and Diet Selection in Farm Animals. Wallingford, Oxon: CAB INTERNATIONAL. 
Gibson, E. L. \& Booth, D. A. (1986). Acquired protein appetite in rats: dependence on a protein-specific need state. Experientia 42, $1003-1004$.

Gietzen, D. W. (1993). Neural mechanisms in the responses to amino acid deficiency. Journal of Nutrition 123, 610-625.

Gietzen, D. W., Leung, P. M. B. \& Rogers, Q. R. (1986). Norepinephrine and amino acids in prepyriform cortex of rats fed imbalanced amino acid diets. Physiology and Behavior 36, 1071-1080.

Hach, C.C., Brayton, S.V. \& Kopelove, A. (1985). A powerful Kjeldahl nitrogen method using peroxymonosulfuric acid. Journal of Agricultural and Food Chemistry 33, 1117-1123.

Hemsley, J.A. \& Moir, R.J. (1963). The influence of higher volatile fatty acids on the intake of ureasupplemented low-quality cereal hay by sheep. Australian Journal of Agricultural Science 14, 509-517.

Hou, X.Z., Emmans, G. C., Anderson, D., Illus, A. \& Oldham, J. D. (1991). The effect of different pairs of feeds offered as a choice on food selection by sheep. Proceedings of the Nutrition Society 50, 94A.

Huber, J. T. \& Cook, R. M. (1972). The influence of site of administration of urea on voluntary intake of concentrate by lactating cows. Journal of Dairy Science 55, 1470-1473.

Huber, J. T. \& Herrera-Saldana, R. (1994). Synchrony of protein and energy supply to enhance fermentation. In Principles of Protein Nutrition of Ruminants, pp. 113-126 [J. M. Asplund, editor]. Boca Raton, FL: CRC Press Inc.

Kempton, T. J. \& Leng, R. A. (1979). Protein nutrition of growing lambs. 1. Responses in growth and rumen function to supplementation of a low-protein-cellulosic diet with either urea, casein, or formaldehyde-treated casein. British Journal of Nutrition 42, 289-302.

Kempton, T. J., Nolan, J. V. \& Leng, R. A. (1979). Protein nutrition of growing lambs. 2. Effect on nitrogen digestion of supplementing a low-protein-cellulosic diet with either urea, casein or formaldehyde-treated casein. British Journal of Nutrition 42, 303-315.

Kertz, A. F., Koepke, M. K., Davidson, L. E., Betz, N. L., Norris, J. R., Skoch, L. V., Cords, B. R. \& Hopkins, D. T. (1982). Factors influencing intake of high urea-containing rations by lactating dairy cows. Journal of Dairy Science 65, 587-604.

Kyriazakis, I. \& Oldham, J. D. (1993). Diet selection in sheep: the ability of growing lambs to select a diet that meets their crude protein (nitrogen $\times 6.25$ ) requirements. British Journal of Nutrition 69, 617-629.

Kyriazakis, I., Oldham, J.D., Coop, R. L. \& Jackson, F. (1994). The effect of subclinical intestinal nematode infection on the diet selection of growing sheep. British Journal of Nutrition 72, 665-677.

Langvatn, R. \& Hanley, T.A. (1993). Feeding-patch choice by red deer in relation to foraging efficiency. Oecologia 95, 164-170.

Leng, R. A. (1990). Factors affecting the utilization of 'poor quality' forages by ruminants particularly under tropical conditions. Nutrition Research Reviews 3, 277-303.

MacRae, J.C. \& Lobley, G.E. (1988). Interactions between energy and protein. In Control of Digestion and Metabolism in Ruminants, pp. 367-385 [L.P. Milligan, W. L. Grovum and A. Dobson, editors]. Englewood Cliffs, NJ: Prentice-Hall.

Matras, J., Bartle, S. J. \& Preston, R.L. (1991). Nitrogen utilization in growing lambs: effects of grain (starch) and protein sources with various rates of ruminal degradation. Journal of Animal Science 69, 339347.

Mehiel, R. (1991). Hedonic-shift conditioning with calories. In The Hedonics of Taste, pp. 107-126 [R.C. Bolles, editor]. Hillsdale, NJ: Lawrence Erlbaum Associates.

Merchen, N. R. \& Titgemeyer, E.C. (1992). Manipulation of amino acid supply to the growing ruminant. Journal of Animal Science 70, 3238-3247.

Mook, D. G. (1988). On the organization of satiety. Appetite 11, 27-39.

Mugerwa, J.S. \& Conrad, H. R. (1971). Relationship of dietary nonprotein nitrogen to urea kinetics in dairy cows. Journal of Nutrition 101, 1331-1342.

Nicholson, J. W. G., Charmley, E. \& Bush, R. S. (1992). The effect of supplemental protein source on ammonia leveis in rumen fluid and blood and intake of alfalfa silage by beef cattle. Canadian Journal of Animal Science 72, 853-862.

Noach, E. L. (1994). Appetite regulation by serotoninergic mechanisms and effects of D-fenfluramine. Netherlands Journal of Medicine 45, 123-133.

National Research Council (1985). Nutrient Requirements of Sheep. Washington, DC: National Academy Press.

Oldham, J. D. (1993). Recent progress towards matching feed quality to the amino acid needs of ruminants. Animal Feed Science and Technology 45, 19-34.

Ørskov, E. R. (1982). Protein Nutrition in Ruminants. London: Academic Press.

Owens, F. N. (1988). Protein metabolism of ruminant animals. In The Ruminant Animal. Digestive Physiology and Nutrition pp. 227-249. [D. C. Church, editor]. Englewood Cliffs, NJ: Prentice-Hall Inc.

Prior, R. L., Clifford, A. J., Hogue, D.E. \& Visek, W. J. (1970). Enzymes and metabolites of intermediary metabolism in urea-fed sheep. Journal of Nutrition 100, 438-444.

Provenza, F. D. (1995a). Postingestive feedback as an elementary determinant of food preference and intake in ruminants. Journal of Range Management 48, 2-17. 
Provenza, F. D. (1995b). Role of learning in food preferences of ruminants: Greenhalgh and Reid revisited. In Ruminant Physiology: Digestion, Metabolism, Growth and Reproduction. Proceedings VIII International Symposium on Ruminant Physiology, pp. 231-245 [W. V. Engelhardt, S. Leonhard-Marek, G. Breves and D. Giesecke, editors]. Stuttgart, Germany: Ferdinand Enke Verlag.

Provenza, F. D. (1996). Acquired aversions as the basis for varied diets of ruminants foraging on rangelands. Journal of Animal Science 74, 2010-2020.

Provenza, F. D., Scott, C. B., Phy, T.S. \& Lynch, J. J. (1996). Preference of sheep for foods varying in flavors and nutrients. Journal of Animal Science 74, 2355-2361.

Ralphs, M. H., Provenza, F. D., Wiedmeier, W. D. \& Bunderson, F. B. (1995). The effects of energy source and food flavor on conditioned preferences in sheep. Journal of Animal Science 73, 1651-1657.

Redman, R. G., Kellaway, R. C. \& Leibholz, J. (1980). Utilization of low quality roughages: effects of urea and protein supplements of differing solubility on digesta flows, intake and growth rate of cattle eating oaten chaff. British Journal of Nutrition 44, 343-354.

Rogers, Q.R. \& Egan, A.R. (1975). Amino acid imbalance in the milk-fed lamb. Australian Journal of Biological Science 28, 169-182.

Romesburg, H.C. (1981). Wildlife Science: gaining reliable knowledge. Journal of Wildlife Management 45, 293-313.

Russell, J. B., O'Connor, J.D., Fox, G. G., Van Soest, P. J. \& Sniffen, C. J. (1992). A net carbohydrate and protein system for evaluating cattle diets. I. Ruminal fermentation. Journal of Animal Science 70, 3551-3561.

Santos, K. A., Stern, M. D. \& Satter, L. D. (1984). Protein degradation in the rumen and amino acid absorption in the small intestine of lactating dairy cattle fed various protein sources. Journal of Animal Science 58, 244 255.

Scott, T. R. (1990). The effect of physiological need on taste. In Taste, Experience, and Feeding, pp. 45-61 [E. D. Capaldi and T.L. Powley, editors]. Washington, DC: American Psychological Association.

Sinclair, L. A., Garnsworthy, P. C., Newbold, J. R. \& Buttery, P. J. (1993). Effect of synchronizing the rate of dietary energy and nitrogen release on rumen fermentation and microbial protein synthesis in sheep. Journal of Agricultural Science, Cambridge 120, 251-263.

Storm, E. \& Ørskov, E. R. (1983). The nutritive value of rumen micro-organisms in ruminants. 1. Large scale isolation and chemical composition of rumen micro-organisms. British Journal of Nutrition 50, 463-470.

Storm, E. \& Ørskov, E. R. (1984). The nutritive value of rumen micro-organisms in ruminants. 4. The limiting amino acids of microbial protein in growing sheep determined by a new approach. British Journal of Nutrition 52, 613-620.

Umunna, N. N. (1982). Utilization of poor quality roughages: response of sheep fed mature hay supplemented with urea by different methods. Journal of Agricultural Science, Cambridge 98, 343-346.

Villalba, J. J. \& Provenza, F.D. (1997). Preference for wheat straw by lambs conditioned with intraruminal infusions of starch. British Journal of Nutrition 77, 287-297.

Villalba, J.J. \& Provenza, F.D. (1996). Preference for flavored wheat straw by lambs conditioned with intraruminal administrations of sodium propionate. Journal of Animal Science 74, 2362-2368.

Visek, W. J. (1968). Some aspects of ammonia toxicity in animal cells. Journal of Dairy Science 51, $286-295$.

Willms, C. L., Berger, L. L., Merchen, N. R. \& Fahey, G.C., Jr (1991). Effects of supplemental protein source and level of urea on intestinal amino acid supply and feedlot performance of lambs fed diets based on alkaline hydrogen peroxide-treated wheat straw. Journal of Animal Science 69, 4925-4938.

Wilmshurst, J.F., Fryxell, J. M. \& Hudson, R. J. (1995). Forage quality and patch choice by wapiti (Cervus elaphus). Behavioral Ecology 6, 209-217.

Wilson, G. W., Martz, F. A., Campbell, J.R. \& Becker, B.A. (1975). Evaluation of factors responsible for reduced voluntary intake of urea diets for ruminants. Journal of Animal Science 41, 1431-1437.

Wurtman, R. J. \& Wurtman, J. J. (1986). Carbohydrate craving, obesity and brain serotonin. Appetite 7 Suppl., 99-103.

Zahorik, D. M. \& Houpt, K. A. (1977). The concept of nutritional wisdom: applicability of laboratory learning models to large herbivores. In Learning Mechanisms in Food Selection, pp. 45-70. [L. M. Barker, M. R. Best and M. Domjan, editors]. Waco, TX: Baylor University Press. 